\title{
Some Physical and Chemical Properties of Mango Fruits
}

\author{
Esraa H. Kabeel ${ }^{1}$, El-Sayed G. Khater ${ }^{2}$ Adel H. Bahnasawy ${ }^{3}$ and Ahmed A.R. Atawia ${ }^{4}$ \\ ${ }^{1}$ MSc Stud. of Agric. Eng. Dep., Fac. of Agric., Benha Univ., Egypt \\ ${ }^{2}$ Assoc. Prof. of Agric. Eng., Fac. of Agric., Benha Univ., Egypt \\ ${ }^{3}$ Prof. of Agric. Eng., Fac. of Agric., Benha Univ., Egypt \\ ${ }^{4}$ Prof. of Hort., Fac. of Agric., Benha Univ., Egypt \\ Corresponding author: alsayed.khater@fagr.bu.edu.eg
}

\begin{abstract}
The main aim of this work was to study the physical and chemical properties of mango fruits. The results indicated that, the major, intermediate and minor diameter of mango fruit (Zebda cultivar) values ranged from 9.14 to $11.19,6.63$ to 7.54 and 5.08 to $6.40 \mathrm{~cm}$, respectively. The geometric mean diameter and arithmetic mean diameter of the mango fruits ranged from 6.62 to 7.58 and 6.94 to $8.07 \mathrm{~cm}$, respectively. The surface area, volume and real density of mango fruits values ranged from 137.61 to $188.60 \mathrm{~cm}^{2}, 368.33$ to $586.00 \mathrm{~cm}^{3}$ and 899 to $923 \mathrm{~kg} \mathrm{~m}^{-3}$, respectively. The weight of pulp, peel and seed of mango fruit values ranged from 250.00 to $414.97,44.34$ to 61.00 and 39.44 to $50.45 \mathrm{~g}$, respectively, for different sizes of mango fruits. The TSS of the mango fruits were ranged from 8.15 to $9.14 \%$. The total sugar, reducing and non-reducing sugars of the mango fruits were 7.18 to $7.73,4.55$ to 4.93 and 2.62 to $2.80 \%$, respectively, for all treatments. The chlorophyll a, chlorophyll $\mathrm{b}$ and carotenoids of the mango fruits were 6.29 to $6.86,3.76$ to 3.85 and 2.99 to $3.02 \%$, respectively. The N, P and K content of the mango fruits were 1.167 to $1.200,0.373$ to 0.397 and 1.357 to $1.403 \%$ for categories A, B, C, D and E, respectively.
\end{abstract}

Keywords: Mango, physical properties, chemical properties, dimensions, surface area, volume, density, TSS

\section{Introduction}

Mango (Mangifera indica L., Family Anacardiaceae) is well known as the queen of fruits that has an excellent exotic flavor. Commercial mango production is reported in more than 87 countries. India, China, Thailand, Indonesia, Philippines, Pakistan and Mexico are the prominent mango producing countries (Sivakumar et al., 2011). Central and South America, Australia, Southeast Asia, Hawaii, Egypt and South Africa are outside the traditional geographical regions for mango production and are increasing the mango cultivations especially for export markets (Tharanathan et al., 2006).

It is one of the most important tropical fruit in the world, it is greatly relished for its succulence, exotic flavor and delicious taste in most countries of the world. Apart from its delicacy, it is a nutritionally important fruit being a good source of vitamin A, B and $\mathrm{C}$, and minerals (Bhatnagar and Subramanyam, 2011). Mango production in 2010 was 39 million tons (including mango stones and guava). Mango is seasonal fruit and about 20 percent of the fruits are processed for products such as puree, nectar, leather, canned slice and chutney, juices, ice cream, fruit bars, and pies. During the processing of ripe mango, its peel and seed are generated as a waste, which is approximately $40-50 \%$ of the total fruit weight (Ashoush and Gadallah, 2011).
Knowledge of dimensions, volume, surface area and mass of the product is necessary to: (a) the design of sorting and grading machines (b) predicting amounts of surface applied chemicals and (c) describing heat and mass transfer during thermal processes and in quantification of bruise, abrasion and damage in handling process. The shape of some fruits is important in determining their suitability for processing as well as their retail value. Many researches have been carried out on the physical and engineering properties of many agricultural products (Khater and Bahnasawy, 2016). The information on size, density, and crushing strength are required for the development of grading system for barriers and for the pulpers (Gosh, 1969). The physical and mechanical properties such as size, friction angle, angle of repose, crushing strength and bulk density are important in the design of the handling system and grading (Chandrasekar and Viswanathan, 1999).

A study of the physical properties of biomaterials is essential for the design of processing machines, storage structures and environmental parameter controls. Such data are useful in the analysis and determination of the efficiency of a machine or an operation, development of new products and new equipment and final quality of new products (Mohsenin, 1986). The size of agricultural materials such as grains, pulses and oil seeds have been described by measuring their principal axial dimensions (Oje et al., 2001 and Perez-Alegria et al., 
2001). Geometrical mean of the axial dimensions have also been shown to be adequate for calculating Reynold's number, projected areas and drag coefficient of food grain. These parameters are needed in the design of machine for pneumatic conveying, fluidization and separation of ground straw mixtures (Gorial and O'Callaghan, 1990). Density and specific gravity of biomaterials play important roles in many applications, and are useful in drying and storage of hay products, design of silos and storage bins.

Physical indices will help to determine the fruit optimal harvest time. These are: mass, size, shape, color, firmness, and number of days after flowering. Information on the fruit mechanical properties is also important to determine the fruit's degree of maturation. Consequently, compression tests may be employed to obtain force deflection curves to check fruit firmness (Khater et al., 2014).

A complete knowledge of these properties is vital for developing and selecting the equipment required in the processes of harvesting, packaging, storage and transportation. These will guarantee the process will achieve maximum efficiency without compromising the product final quality (Lima et al., 2014). An extensive knowledge of the development of mango ripening under regional growing conditions, will certainly expand the fruit life (Lima et al., 2009), as it will allow the use of acceptable control practices before harvest, reducing losses and preserving fruit quality.

Export problems are mainly from the lack of physical and chemical properties knowledge. Physical and chemical properties are important in many problems associated with the design of machines and the analysis of the behaviour of the product during agricultural processing operations such as handling, planting, harvesting, milling, threshing, cleaning, grading, sorting and drying, therefore, the main aim of this investigation is to study some physical and chemical properties of the mango fruits.

\section{Materials and Methods}

The experiment was carried out at Horticulture Research Institute, Agriculture Research Center, Giza, Egypt, during the period of August and September, 2019.

\subsection{Materials:}

Fruits of mango (Mangifera indica L.) were carefully harvested at the same maturity stage. The mango fruits (Zebda cultivar) were used in this study to measure and determine the physical and chemical properties.

Mango fruits were divided into five categories from (A) to (E) according to the fruit weights as shown in the following Group A: fruit weight from 300 to 350 gram. Group B: fruit weight from 350 to 400 gram. Group C: fruit weight from 400 to 450 gram. Group D: fruit weight from 450 to 500 gram. Group E: fruit weight from 500 to 550 gram and each group was replicated three times while, each replicate was represented by (6) fruits since and the complete randomized design was used.

\subsection{Methods:}

1.2.1. Physical and chemical properties:

1.2.1.1. Physical properties:

For each mango fruit, three principle diameters (axial dimension); major diameter (a), intermediate diameter (b) and minor diameter (c) were measured using digital vernier caliper (Model TESA 1p65Range $0-150 \mathrm{~mm} \pm 0.01 \mathrm{~mm}$, Swiss) and the average was taken. The geometric mean diameter $(\mathrm{Dg})$ of samples was found using the following formula given by Kacharu et al. (1994):

$$
\mathrm{D}_{\mathrm{g}}=\sqrt[3]{\mathrm{abc}}
$$

Where:

$\mathrm{D}_{\mathrm{g}}$ is the geometric mean diameter, $\mathrm{mm}$ $\mathrm{a}$ is the major diameter of mango fruits, $\mathrm{mm}$ $\mathrm{b}$ is the intermediate diameter of mango fruits, $\mathrm{mm}$ $\mathrm{c}$ is the minor diameter of mango fruits, $\mathrm{mm}$

The arithmetic mean diameter was determined from the three principle diameter using the relationship by (Sunmonu et al., 2015):

$$
\mathrm{D}_{\mathrm{a}}=\frac{a+b+c}{3}
$$

Where:

$\mathrm{D}_{\mathrm{a}}$ is the arithmetric mean diameter, $\mathrm{mm}$

The surface area was determined by using the following equation as cited by Sacilik et al., (2003):

$$
\mathrm{S}=\pi\left(\mathrm{D}_{\mathrm{g}}\right)^{2}
$$

Where:

$\mathrm{S}$ is the fruit surface area, $\mathrm{mm}^{2}$

The sphericity of the mango fruit was calculated by using the following relationship (Sunmonu et al., 2015):

$\phi=\frac{D_{g}}{a} \times 100$

Where:

$\phi$ is the fruit sphericity, $\%$

The mass of fruit mango was measured by electric digital balance (Model Vibra - Range 0-12000 $\mathrm{g} \pm 0.01 \mathrm{~g}$, Japan). Water displacement method was used for determining the fruits measured volume $\left(\mathrm{V}_{\mathrm{m}}\right)$. 
The real density was a measurement of a mango fruits mass per unit volume. For each case, the determination was replicated three times and the mean was considered.

The moisture content of randomly selected mango fruits was determined according to $\mathbf{A S A E}$ Standard (1984). Three samples of each mango fruits were randomly selected and weighed on an electric digital balance. Drying oven (Model 655F Cat. No. 13245-655, range 50 to $300{ }^{\circ} \mathrm{C}$, Canada) at $70^{\circ} \mathrm{C}$ until a constant weight was used to measure the moisture content.

\subsubsection{Chemical Properties:}

The TSS was measured by Refractometer (Model HR- 010-Range 0- 10\% Brix $\pm 0.1 \%$ Brix, Japan) according to Chen and Mellenthin (1981).

The total titratable acidity was determined in terms of anhydrous citric acid percentage after fruit juice sample $(5 \mathrm{~mL})$ was used and titrated with $0.1 \mathrm{~N}$. sodium hydroxide solution in the presence phenolphthalein $(1.0 \%)$ as an indicator according Vogel (1975) titratable acidity was estimated and expressed as mg of citric acid per $100 \mathrm{ml}$ of fruit juice.

Ascorbic acid content (vitamin C) was determined using sample of fruit juice $(5 \mathrm{~mL})$ and $(5$ $\mathrm{mL}$ ) of oxalic acid solution (4\%) were added to each sample then, each sample was titrated with 2.6 dichlorophenol-indophenoldye and applying the following formula according to the method described by A.O.A.C. (2000):

$$
\text { Ascorbic acid }=\frac{V \times T}{W} \times 100
$$

Where:

$\mathrm{V}$ is the volume made up, mg per $100 \mathrm{~g}$ fresh weight

$\mathrm{T}$ is the dye factor

$\mathrm{W}$ is the weight of sample, $\mathrm{g}$

The sugars contents were extracted from ( $5 \mathrm{~g})$ of fruit fresh flesh as samples. The extraction was carried out using distilled water according to Loomis and Shull (1937). For determination of sugars the reducing as well as the total sugars of the extract were determined respectively, before and after hydrolysis with hydrochloric acid by Nelson arseno molybedate colorimetric method described by Malik and Singh (1980). The non-reducing sugars were calculated by subtracting reducing sugars from total sugars as following:

Non - reducing sugars $=$ totalsugars - reducing suga

Fruit pigments were determined in terms of chlorophyll A, B and carotenoids in peel as well as carotenoids in the pulp tissues with acetone and washed sand until all green pigments were extracted. The extract was than filtered and made up to final volume with $85 \%$ acetone. As for the carotenoids in pulp, a known weight of the pulp of fruit was extracted with chilled acetone $(85 \%)$ till the extract was colour less than filtered and made up to final volume with $(85 \%)$ acetone. The optical densities of the filtrates were determined by Carl Zeuss photo-electric colorimeter at 660, 640 and $440 \mathrm{~nm}$ wavelength by method of Saric et al., (1976).

$$
\begin{aligned}
& \text { Chlorophyll }(\mathrm{A})=9.784 \times \mathrm{E}(662)-0.99 \times \mathrm{E}(644) \\
& \text { Chlorophy } 1 \mathrm{l}(\mathrm{B})=21.426 \times \mathrm{E}(662)-4.65 \times \mathrm{E}(662) \\
& \text { Carotenoids }=9.695 \times \mathrm{E}(440)-0.268 \times(\text { Chlor. A }+\mathrm{B}) \\
& \text { Where }
\end{aligned}
$$

$\mathrm{E}$ is the optical density at given wave length

Total content of macro elements were evaluated after being digested according to Chapman and Partt (1961). Nitrogen was determined by Kjeldahl digestion apparatus (Bremmer and Mulvaney, 1982). Potassium was determined by Photofatometer (Model Jenway PFP7 - Range 0 - 160 mmol L $\mathrm{L}^{-1}$, USA) and phosphorus (P) was determined colorimetrically following the Murphy and Riley (1962) method.

\subsection{Statistical analysis:}

All the obtained data during the experimental season of study were analysis of variance method according to Snedecor and Cochran (1990). However, the significant differences among means determined according to Duncan's multiple range test (Duncan, 1955).

\section{Results and Discussions}

\subsection{Physical properties}

Table (1) shows the diameters (major diameter, intermediate diameter and minor diameter), geometric mean diameter and arithmetic mean diameters of the mango fruits for different categories. It could be seen that the major diameters of mango fruits were $9.14,10.23,10.81,10.89$ and $11.19 \mathrm{~cm}$ for categories A, B, C, D and E, respectively. The intermediate diameters of mango fruits were 6.63, 7.09, $7.17,7.53$ and $7.54 \mathrm{~cm}$ for categories A, B, C, D and E, respectively. The minor diameters of mango fruits were $5.08,5.49,6.40,5.80$ and $5.49 \mathrm{~cm}$ for categories A, B, $\mathrm{C}, \mathrm{D}$ and $\mathrm{E}$, respectively. The highest values of major, intermediate and minor diameters of mango fruits were $11.19,7.54$ and $5.49 \mathrm{~cm}$ were found for category E. While, the lowest values of major, intermediate and minor diameters of mango fruits were 9.14, 6.63 and $5.08 \mathrm{~cm}$ were found for category A. The results also indicate that the geometric mean diameter and 
arithmetic mean diameters of the mango fruits increases with increasing fruit weight. It could be seen that the geometric mean diameter and arithmetic mean diameter of the mango fruits increased from 6.62 to 7.58 and 6.94 to $8.07 \mathrm{~cm}$, respectively, when the fruit weight increased from $300 \mathrm{~g}$ (category A) to $400 \mathrm{~g}$ (category E). These dimensions data are very important in handling, packing and storage capacity determination. These results were in agreement with those obtained by Fawaz (2000) and El-Mehrat (2005).

Table 1. The diameters, geometric mean diameter and arithmetic mean diameter of the mango fruits for different categories.

\begin{tabular}{|c|c|c|c|c|c|c|}
\hline \multirow{2}{*}{ Category } & \multirow{2}{*}{ Fruit Weight, $\mathrm{g}$} & \multicolumn{3}{|c|}{ Diameters, $\mathrm{cm}$} & \multirow{2}{*}{$\begin{array}{c}\text { Geometric mean } \\
\text { diameter, } \mathrm{cm}\end{array}$} & \multirow{2}{*}{$\begin{array}{c}\text { arithmetic mean } \\
\text { diameter, cm }\end{array}$} \\
\hline & & major & Intermediate & Minor & & \\
\hline $\mathrm{A}$ & $300-350$ & $9.14 \mathrm{C}$ & $6.63 \mathrm{C}$ & $5.08 \mathrm{D}$ & $6.62 \mathrm{~A}$ & $6.95 \mathrm{~A}$ \\
\hline B & $350-400$ & $10.23 \mathrm{~B}$ & 7.09B & $5.49 \mathrm{C}$ & $7.21 \mathrm{~B}$ & $7.60 \mathrm{~B}$ \\
\hline $\mathrm{C}$ & $400-450$ & $10.81 \mathrm{~A}$ & $7.17 \mathrm{~B}$ & $6.40 \mathrm{~A}$ & $7.75 \mathrm{C}$ & $8.13 \mathrm{C}$ \\
\hline $\mathrm{D}$ & $450-500$ & $10.89 \mathrm{~A}$ & $7.53 \mathrm{~A}$ & $5.80 \mathrm{~B}$ & $7.65 \mathrm{C}$ & $8.07 \mathrm{C}$ \\
\hline $\mathrm{E}$ & $500-550$ & $11.19 \mathrm{~A}$ & 7.54A & $5.49 \mathrm{C}$ & $7.58 \mathrm{C}$ & $8.07 \mathrm{C}$ \\
\hline \multicolumn{2}{|c|}{ Mean } & 10.45 & 7.19 & 5.65 & 7.37 & 7.76 \\
\hline
\end{tabular}

Table (2) shows the weight, volume, real density and firmness of the mango fruits for different categories. It could be seen that the mango fruits weight were $333.78,377.00,432.00,477.00$ and $527.00 \mathrm{~g}$ for categories A, B, C, D and E, respectively. The results indicate that the fruit volume increases with increasing fruit weight. It could be seen that the volume of the mango fruits increased from 368.33 to $586.00 \mathrm{~cm}^{3}$, when the fruit weight increased from 300 $\mathrm{g}$ (category A) to $400 \mathrm{~g}$ (category E). The results also indicate that the real density of mango fruits decreases with increasing fruit weight. It could be seen that the real density decreased from 923 to $899 \mathrm{~kg} \mathrm{~m}^{-3}$, when the fruit weight increased from $300 \mathrm{~g}$ (category A) to $400 \mathrm{~g}$ (category E). In other words, the highest value of fruit weight $(527.0 \mathrm{~g})$ was the inferior as exhibited the least value of fruit density $\left(899 \mathrm{~kg} \mathrm{~m}^{-3}\right)$. On the other hand, the reverse trend was true with the lowest value of fruit weight (333.78 g) which was the superior hence, it resulted in the highest value of fruit density $\left(923 \mathrm{~kg} \mathrm{~m}^{-3}\right)$. Moreover, other remain of fruit weights (377.0, 432.0 and $477.0 \mathrm{~g}$ ) of mango fruits were ranked the second, third and fourth whereas, they exhibited the intermediate values between the abovementioned two extents (918, 905 and $904 \mathrm{~kg} \mathrm{~m}^{-3}$ ) respectively. Generally, the present results in most cases are in a partial agreement with those mentioned by Fawaz (2000) on many varieties and cultivars of mango fruits.

The results also indicate that the mango fruit surface area increases with increasing fruit weight. It could be seen that the mango fruit surface area increased from 137.61 to $188.60 \mathrm{~cm}^{2}$, when the fruit weight increased from $300 \mathrm{~g}$ (category A) to $400 \mathrm{~g}$ (category E), respectively. The highest value of mango fruit surface area $\left(188.60 \mathrm{~cm}^{2}\right)$ was found with category $\mathrm{E}$, while the lowest value of mango fruit surface area $\left(137.61 \mathrm{~cm}^{2}\right)$ was found with category A. The results also indicate that the sphericity decreases with increasing fruit weight. It could be seen that the mango fruit sphericity decreased from 72.43 to $67.74 \%$, when the fruit weight increased from $300 \mathrm{~g}$ (category A) to $400 \mathrm{~g}$ (category E), respectively. The highest value of mango fruit sphericity $(72.43 \%$ ) was found with category A, while the lowest value of mango fruit sphericity $(67.74 \%)$ was found with category E. Table (3) and figures (1a, b, c, d and e) show the weight of pulp, peel and seed of mango fruits. It could be seen that the weight of pulp, peel and seed of mango fruit values ranged from 250.00 to 414.97 , 44.34 to 61.00 and 39.44 to $50.45 \mathrm{~g}$, respectively, for different sizes of mango fruits.

Table 2. The weight, volume, real density, surface area and sphericity of the mango fruits for different categories.

\begin{tabular}{|c|c|c|c|c|c|c|}
\hline Category & Fruit Weight, $\mathrm{g}$ & Weight, $\mathrm{g}$ & Volume, $\mathrm{cm}^{3}$ & Density, $\mathrm{kg} \mathrm{m}^{-3}$ & $\begin{array}{c}\text { Surface } \\
\text { Area, } \mathrm{cm}^{2}\end{array}$ & Sphericity, \% \\
\hline A & $300-350$ & $333.78 \mathrm{E}$ & $368.33 \mathrm{E}$ & $0.923 \mathrm{~A}$ & $137.61 \mathrm{D}$ & $72.43 \mathrm{~A}$ \\
\hline $\mathrm{B}$ & $350-400$ & $377.00 \mathrm{D}$ & 408.33D & $0.918 \mathrm{~A}$ & $163.23 \mathrm{C}$ & $71.69 \mathrm{~A}$ \\
\hline $\mathrm{C}$ & $400-450$ & $432.00 \mathrm{C}$ & $477.23 \mathrm{C}$ & $0.905 \mathrm{~A}$ & 180.41B & $70.48 \mathrm{~B}$ \\
\hline $\mathrm{D}$ & $450-500$ & 477.00B & 528.33B & $0.904 \mathrm{~A}$ & 183.76B & $70.25 \mathrm{~B}$ \\
\hline $\mathrm{E}$ & $500-550$ & $527.0 \mathrm{~A}$ & $586.00 \mathrm{~A}$ & $0.899 \mathrm{~A}$ & $188.60 \mathrm{~A}$ & $67.74 \mathrm{C}$ \\
\hline \multicolumn{2}{|r|}{ Mean } & 429.36 & 429.64 & 0.910 & 170.72 & 70.52 \\
\hline
\end{tabular}


Table 3. The weight of pulp, peel and seed of mango fruits.

\begin{tabular}{|c|c|c|c|c|c|c|c|c|}
\hline \multirow{3}{*}{ Category } & \multirow{3}{*}{ Fruit Weight, $g$} & \multirow{3}{*}{ Weight, g } & \multicolumn{6}{|c|}{ Fruit Weight, $\mathrm{g}$} \\
\hline & & & \multicolumn{2}{|c|}{ Pulp } & \multicolumn{2}{|c|}{ Peel } & \multicolumn{2}{|c|}{ Seed } \\
\hline & & & $\mathrm{G}$ & $\%$ & $\mathrm{~g}$ & $\%$ & $\mathrm{G}$ & $\%$ \\
\hline A & $300-350$ & $333.78 \mathrm{E}$ & $250.00 \mathrm{E}$ & 74.90D & $44.34 \mathrm{E}$ & $13.27 \mathrm{~A}$ & $39.44 \mathrm{D}$ & $11.81 \mathrm{~A}$ \\
\hline B & $350-400$ & 377.00D & $252.53 \mathrm{D}$ & $74.83 \mathrm{D}$ & $50.33 \mathrm{D}$ & $13.24 \mathrm{~A}$ & $44.00 \mathrm{C}$ & $11.67 \mathrm{~A}$ \\
\hline $\mathrm{C}$ & $400-450$ & $432.00 \mathrm{C}$ & $329.87 \mathrm{C}$ & $76.32 \mathrm{C}$ & $54.78 \mathrm{C}$ & $12.66 \mathrm{~B}$ & $47.33 \mathrm{~B}$ & $10.85 \mathrm{~B}$ \\
\hline D & $450-500$ & $477.00 \mathrm{~B}$ & $373.00 \mathrm{~B}$ & 78.19B & $56.00 \mathrm{~B}$ & $11.76 \mathrm{C}$ & 47.67B & $10.02 \mathrm{C}$ \\
\hline E & $500-550$ & $527.0 \mathrm{~A}$ & 414.97A & 78.84A & $61.00 \mathrm{~A}$ & $11.62 \mathrm{C}$ & $50.45 \mathrm{~A}$ & $9.57 \mathrm{D}$ \\
\hline & Mean & 429.36 & 330.07 & 76.76 & 53.29 & 12.51 & 45.78 & 10.78 \\
\hline
\end{tabular}
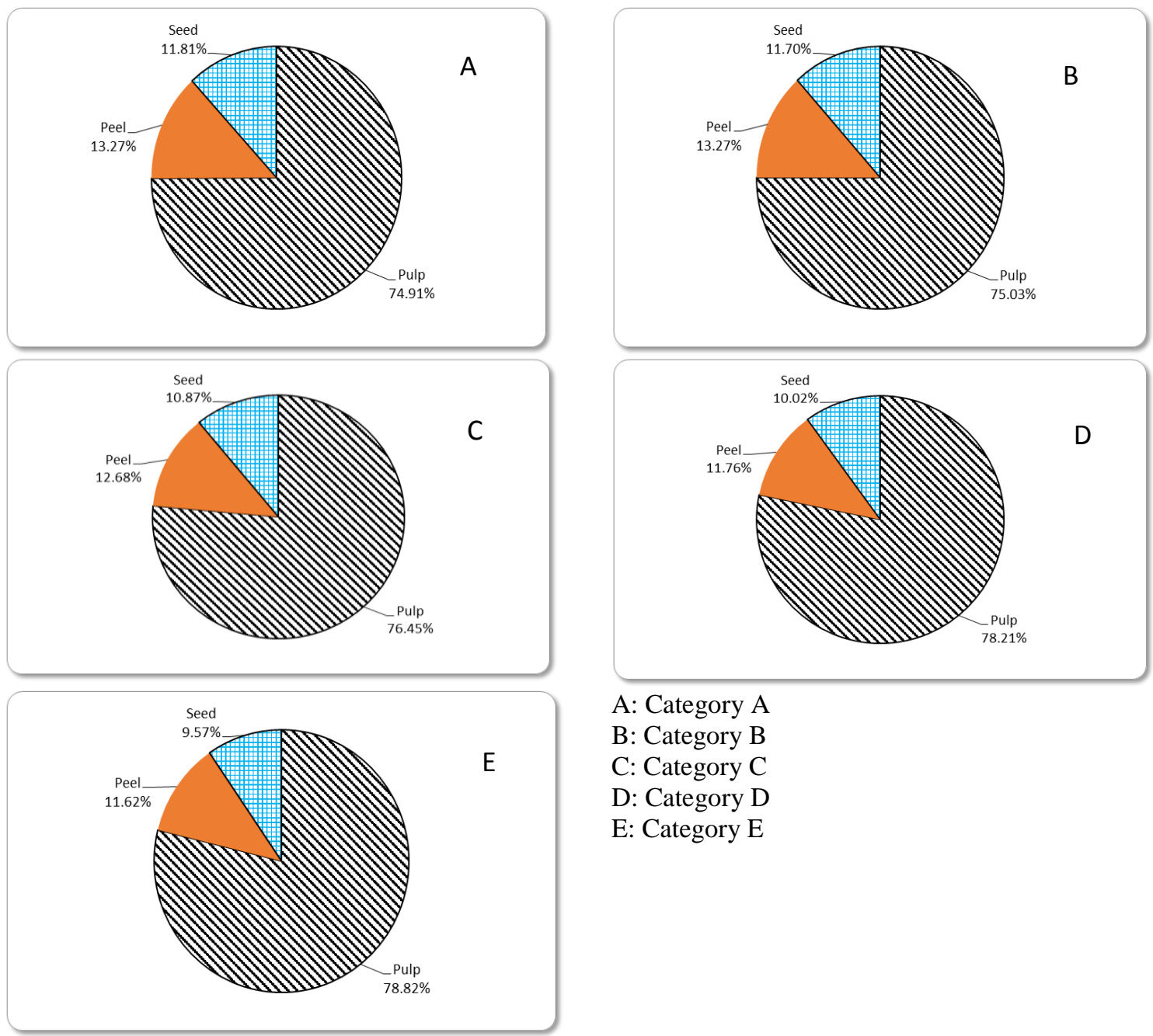
A: Category A
B: Category B
C: Category $\mathrm{C}$
D: Category D
E: Category E

Figure (1): Weight of pulp, peel and seed of mango fruits.

\subsection{Chemical properties:}

Table (4) shows the total soluble solids (TSS), total acidity, total soluble solids/ total acidity ratio and ascorbic acid of the mango fruits "Zebra" cultivar. The results indicated that the TSS of the mango fruits were $8.15,8.30,8.77,9.06$ and $9.14 \%$ for categories A, B, $\mathrm{C}, \mathrm{D}$ and $\mathrm{E}$, respectively. Whereas, a gradual increase in fruit juice TSS content was continuously occurred as fruit weight rate increased. However, the highest rate of fruit weight i.e., $(\mathrm{E}=527.0 \mathrm{~g})$ had the richest fruits in their TSS content and exhibited the greatest value of TSS $(9.14 \%)$, followed by both fruit weight rates ( $\mathrm{D}=$ $477.0 \mathrm{~g})$ and $(\mathrm{C}=432.0 \mathrm{~g})$ which were induced TSS values ranked second and third i.e., $(9.06 \%)$ and $(8.77$ $\%)$, respectively. However, it could be observed that, 
the differences between the three abovementioned rates of fruit weights were so little, whereas they showed the same effectiveness from the standpoint of statistics. On the other hand, the poorest fruits in their TSS content and the lowest value $(8.15 \%)$ was resulted by the lightest mango fruit weight rate $(\mathrm{A}=333.78 \mathrm{~g})$. Generally, it could be observed from obtained results in this study that, the mean value of TSS in fruit juice mango (Zebda cultivar) was approximately $(8.68 \%)$.

Regarding the total acidity percentage of Zebda mango fruits in response to the various investigated fruit weights under study, it is quite evident from obtained results in table (4) that, a negatively relationship was found between both total acidity content in fruit juice and the rates of fruit weights under study. In other words, total acidity content decreased gradually with an increasing the rate of fruit weights. However, fruit juice total acidity content reached to its maximum value $(\mathrm{A}=2.17 \%)$ with the lightest Zebda mango fruits $\mathrm{cv}$., which weighed about $(A=333.78 \mathrm{~g})$, followed in a descendingly order by the rates of fruit weight i.e., $(\mathrm{B}=377.0 \mathrm{~g}),(\mathrm{C}=432.0 \mathrm{~g})$ and $(\mathrm{E}=527 \mathrm{~g})$ which were exhibited total acidity values ranked second, third and fourth i.e., (2.14\%), $(2.12 \%)$ and $(2.11 \%)$, respectively. Meanwhile, the rates of the fruits i.e., ( $\mathrm{D}=477.0 \mathrm{~g}$ ) of mango fruits were induced the poorest and the lowest (minimum) values of fruit juice total acidity contents i.e., $(\mathrm{D}=$ $2.08 \%$ ). In general, it could be noticed from data in this work that, the mean value of total acidity content in mango Zebda cv., fruit juice was about $(2.12 \%)$.

Table 4. The total soluble solids (TSS), total acidity, total soluble solids/ total acidity ratio and ascorbic acid of the mango fruits.

\begin{tabular}{cccccc}
\hline Category & Fruit Weight, $\mathrm{T}$ & TSS, $\%$ & TA, $\%$ & TSS/TA ratio & $\begin{array}{c}\text { Ascorbic acid (vit. C), } \\
\mathrm{mg} / 100 \mathrm{ml}\end{array}$ \\
\hline $\mathrm{A}$ & $300-350$ & $8.15 \mathrm{~B}$ & $2.17 \mathrm{~A}$ & $3.77 \mathrm{~B}$ & $49.84 \mathrm{C}$ \\
$\mathrm{B}$ & $350-400$ & $8.30 \mathrm{~B}$ & $2.14 \mathrm{~A}$ & $3.89 \mathrm{~B}$ & $51.91 \mathrm{~B}$ \\
$\mathrm{C}$ & $400-450$ & $8.77 \mathrm{AB}$ & $2.12 \mathrm{AB}$ & $4.15 \mathrm{~A}$ & $51.95 \mathrm{~B}$ \\
$\mathrm{D}$ & $450-500$ & $9.06 \mathrm{~A}$ & $2.08 \mathrm{~B}$ & $4.37 \mathrm{~A}$ & $52.09 \mathrm{~B}$ \\
$\mathrm{E}$ & $500-550$ & $9.14 \mathrm{~A}$ & $2.11 \mathrm{AB}$ & $4.23 \mathrm{~A}$ & $54.28 \mathrm{~A}$ \\
\hline \multicolumn{6}{c}{} \\
\hline
\end{tabular}

With respect to the fruit TSS/acid ratio of mango fruits "Zebda" cv., in response to the different rates of fruit weights, data in Table (4) shows clearly that, fruit TSS/acid ratio was increased by increasing the rates of mango fruit weights. However, the richest fruits in their TSS/acid ratio $(4.37,4.23$ and 4.15$)$ were in closed relationship with the heaviest fruits and the highest weights of "Zebda" mango fruits i.e., ( $\mathrm{D}=$ $477.0 \mathrm{~g}, \mathrm{E}=527.0 \mathrm{~g}$ and $432.0 \mathrm{~g}$ ), respectively. On the other hand, an opposite trend was generally always in concomitant to the lightest fruits and the least weight mango fruits i.e., $(\mathrm{A}=333.78 \mathrm{~g}$ and $\mathrm{B}=377.0 \mathrm{~g})$ which exhibited the poorest fruits in the TSS/acid ratio content and the lowest significant value (3.77). Furthermore, an increase in fruit TSS/acid ratio could be explained easily by the occurrence the gradual increase in total soluble solids which was correlated negatively to the changes in level of acidity and consequently an unparalleled trend of both TSS \% and acidity \% was reflected on including such increased in the TSS/acid ratio with advancement the rates of fruit weights.

Obtained results regarding the response of fruit juice total soluble solids (TSS \%), total acidity (\%) and TSS/acidity \% ratio to the different rates of mango fruit weights is coincident with that mentioned by several investigators, Alcantara and Mendoza (1988), Fawaz
(2000) and El-Mehrat (2005) on many mango cultivars and varieties.

With respect to the response of juice total ascorbic acid content (vitamin C) as $\mathrm{mg} / 100 \mathrm{ml}$ juice of Zebda mango fruits cultivar to the different rates of fruit weights, it could be clearly noticed from obtained data represented in table (4) that, fruit juice ascorbic acid content was continuously increased gradually with an increasing the rate of fruit weights. However, it could be observed that, the heaviest and the highest rate of fruit weight i.e., $(\mathrm{E}=527.0 \mathrm{~g})$ showed statistically the greatest and the highest value of fruit juice ascorbic acid content $(54.28 \mathrm{mg} / 100 \mathrm{ml})$ as compared to the other various investigated rates of fruit weights. On the other hand, an opposite trend was inclosed relationship with the lowest rate of fruit weight i.e., $(\mathrm{A}=333.78 \mathrm{~g})$ which was significantly the inferior as exhibited the least value of juice total ascorbic acid content in fruits i.e., $(49.84 \mathrm{mg} / 100 \mathrm{ml})$ than the other rate weights of fruits under study. Moreover, the other three groups of rate weights of mango fruits i.e., $(B=377.0, C=432.0$ and $\mathrm{D}=477.0 \mathrm{~g}$ ) were in between the aforesaid discussed two extents from the standpoint of statistic. Also, data indicated that, the differences between the three abovementioned fruit weights $(\mathrm{B}, \mathrm{C}$ and $\mathrm{D})$ were so very slight to reach level of significance the experimental study. Generally, it could be reported 
that, the mean value of fruit juice total ascorbic acid of mango (Zebda cultivar) is about $(52.01 \mathrm{mg} / 100 \mathrm{ml})$ fruit juice. The present results are in general agreement with those found by Mann et al., (1974) on Langra, Gangwar and Tripathi (1975) on both Dashehari and langra cvs., Gofur et al., (1994) on Ashwini mango cv., and Fawaz (2000) on Alphonse mango cv.

Table (5) shows the total sugar, reducing and nonreducing sugars for the different investigated weight rates of fruit mango (Zebda cultivar) under study. The results indicated that the total sugar, reducing and nonreducing sugars of the mango fruits were 7.18 to 7.73 , 4.55 to 4.93 and 2.62 to $2.80 \%$ for categories A, B, C, $\mathrm{D}$ and $\mathrm{E}$, respectively. The results indicate that the total sugars and reducing as well as non-reducing sugars of mango fruits were in a positive relationship with an increasing the rate of fruit weights from $(\mathrm{A}=333.78 \mathrm{~g})$ to $(\mathrm{E}=527.0 \mathrm{~g})$. In other words, the heaviest fruits and the highest rate of fruit weight i.e., $(\mathrm{E}=527.0 \mathrm{~g})$ was the superior whereas, induced the greatest values of total sugar, reducing and non-reducing sugars content i.e., $(7.73,3.93$ and $3.80 \%)$, respectively. On the other hand, the reverse trend was noticed with the lowest value of the rate of fruit weight whereas, the lightest fruits of mango Zebda cultivar $(\mathrm{A}=333.78 \mathrm{~g})$ was resulted in the least values and the poorest fruits in their sugars content (total, reducing and non-reducing sugars) i.e., (7.18, 3.55 and $3.62 \%$ ) respectively. In addition to that, the other rates of mango fruit weights i.e., $(\mathrm{D}=477.0 \mathrm{~g}, \mathrm{C}=432.0 \mathrm{~g}$ and $\mathrm{B}=377.0 \mathrm{~g})$ came in between the abovementioned two extents. It could be generally observed that, the variation in fruit sugars content between both rates of fruit weights $(C=432.0$ $\mathrm{g}$ and $\mathrm{D}=477.0 \mathrm{~g}$ ) were less pronounced than those previously discussed with other rates of fruit weights under study. The obtained results in the present study are in conformity with those previously reported by Fawaz (2000) and Mehrat (2002) on several cultivars of mango fruits.

Table 5. The total sugar, reducing and non-reducing sugars of the mango fruits.

\begin{tabular}{|c|c|c|c|c|}
\hline Category & Fruit Weight, $\mathrm{g}$ & Total sugars & Reducing sugars & Nom-reducing sugars \\
\hline & & $7.18 \mathrm{C}$ & $4.55 \mathrm{C}$ & $2.62 \mathrm{D}$ \\
\hline B & $350-400$ & $7.48 \mathrm{~B}$ & $4.52 \mathrm{~B}$ & $2.75 \mathrm{C}$ \\
\hline $\mathrm{C}$ & $400-450$ & $7.63 \mathrm{AB}$ & $4.84 \mathrm{AB}$ & $2.79 \mathrm{AB}$ \\
\hline $\mathrm{D}$ & $450-500$ & 7.61AB & $4.83 \mathrm{AB}$ & $2.78 \mathrm{~B}$ \\
\hline $\mathrm{E}$ & $500-550$ & $7.73 \mathrm{~A}$ & $4.93 \mathrm{~A}$ & $2.80 \mathrm{~A}$ \\
\hline \multicolumn{2}{|c|}{ Mean } & 7.53 & 4.78 & 2.75 \\
\hline
\end{tabular}

Table (6) shows the fruit pigments (chlorophyll a, b and carotenoids) in peel as well as carotenoids content in pulp of fruit mango (Zebda cultivar) under study. The results indicated that the chlorophyll a, chlorophyll $\mathrm{b}$ and carotenoids of the mango fruits were 6.29 to 6.86, 3.76 to 3.85 and 2.99 to 3.02 for categories A, B, C, D and E, respectively. Generally, a gradual decrease in both chlorophyll (a) and chlorophyll (b) with an increasing the rate of fruit weights especially with chlorophyll (a). However, the highest significant values of both chlorophyll (a) and chlorophyll (b) were 6.86 and 3.85 were always in concomitant to the lightest fruit weight $(\mathrm{A}=333.78 \mathrm{~g})$ which were the superior for both chlorophyll (a) and (b). Moreover, an opposite trend was detected with the heaviest fruits $(\mathrm{E}=527.0$ g) whereas the least value of chlorophyll (a) was resulted i.e., (6.29) in addition, the other remain three rates of fruit weight i.e., $(\mathrm{B}=377.0 \mathrm{~g}, \mathrm{D}=477.0 \mathrm{~g}$ and $\mathrm{C}=432.0 \mathrm{~g}$ ) were statistically intermediate values as their chlorophyll (a) content i.e., $(6.56,6.55$ and 6.42), respectively. On the other hand, as for chlorophyll (b), the four rates of fruit weight (B, C, D and E) were less effective on chlorophyll (b) content as compared to the rate (A) of fruit weight from the standpoint of statistic and the differences between the abovementioned four rates did not reach level of significance during the study.

Regarding the carotenoids content in peel fruits as affected by the different rates of fruit weight, data in Table (6) showed clearly that the response was so slight and significantly absent, whereas the differences between all investigated weight rates in all cases were not significant and could be safely neglected.

With respect with carotenoids content in pulp of mango fruits was generally responded to the rates of fruit weights. Since, the rate of fruit weight $(C=432.0$ g) induced significantly the greatest value $(0.61)$ as compared to any values of other rates of fruit weights under study, followed statistically in a descending order by the rate of $(\mathrm{E}=527.0 \mathrm{~g})$ and both rates of $(\mathrm{A}=$ 333.78 and $\mathrm{D}=477.0 \mathrm{~g}$ ) whereas both showed the same effectiveness from the standpoint of statistic. On the other hand, the rate of fruit $(\mathrm{B}=377.0 \mathrm{~g})$ was statistically the inferior as exhibited the least value of carotenoids content in pulp i.e., (0.53). 
Table 6. The fruit pigments (chlorophyll a, b and carotenoids) in peel as well as carotenoids content in pulp of the mango fruits.

\begin{tabular}{cccccc}
\hline \multirow{2}{*}{ Category } & \multirow{2}{*}{ Fruit Weight, $\mathrm{g}$} & \multicolumn{3}{c}{ Pigments in peel } & Pulp \\
\cline { 3 - 6 } & & Chlorophyll (A) & Chlorophyll (B) & Carotenoids & Carotenoids \\
\hline A & $300-350$ & $6.86 \mathrm{~A}$ & $3.85 \mathrm{~A}$ & $2.99 \mathrm{~A}$ & $0.57 \mathrm{C}$ \\
$\mathrm{B}$ & $350-400$ & $6.56 \mathrm{~B}$ & $3.75 \mathrm{~B}$ & $3.00 \mathrm{~A}$ & $0.53 \mathrm{D}$ \\
$\mathrm{C}$ & $400-450$ & $6.42 \mathrm{C}$ & $3.68 \mathrm{~B}$ & $3.04 \mathrm{~A}$ & $0.61 \mathrm{~A}$ \\
$\mathrm{D}$ & $450-500$ & $6.55 \mathrm{~B}$ & $3.70 \mathrm{~B}$ & $3.01 \mathrm{~A}$ & $0.57 \mathrm{C}$ \\
$\mathrm{E}$ & $500-550$ & $6.29 \mathrm{D}$ & $3.76 \mathrm{~B}$ & $3.02 \mathrm{~A}$ & $0.59 \mathrm{AB}$ \\
& Mean & 6.54 & 3.75 & 3.01 & 0.57 \\
\hline
\end{tabular}

Table (7) shows some total content of macro elements (N, P and $\mathrm{K}$ ) of fruit mango (Zebda cultivar) under study. The results indicated that the $\mathrm{N}, \mathrm{P}$ and $\mathrm{K}$ content of the mango fruits were 1.167 to $1.200,0.373$ to 0.397 and 1.357 to $1.403 \%$ for categories A, B, C, D and E, respectively. The results indicated that, the richest fruits in their content of both $(\mathrm{N}$ and $\mathrm{K}$ ) was enclosed relationship to the rate of fruit weight $(\mathrm{C}=432.0 \mathrm{~g})$ whereas, the lowest and the poorest fruits in their content of $(\mathrm{N}$ and $\mathrm{K})$ was always in concomitant to the rate least weight $(\mathrm{B}=$ $377.0 \mathrm{~g}$ ) which showed the inferior and induced the least values in this concern. Meanwhile, the reverse trend was observed with the fruit phosphorus content, since the least value and the poorest fruits in their $(\mathrm{P})$ content was resulted from the rate of fruit weight $(\mathrm{C}$ $=432.0 \mathrm{~g}$ ) contrary to that, the rate of fruit weight i.e., $(\mathrm{B}=377.0 \mathrm{gms})$ exhibited the highest values and the richest fruits in their $(\mathrm{P})$ content.

Table 7. Some total content of macro elements (N, P and K) of the mango fruits.

\begin{tabular}{ccccc}
\hline Category & Fruit Weight, $\mathrm{g}$ & Nitrogen N $(\%)$ & Phosphorus P $(\%)$ & Potassium K $(\%)$ \\
\hline A & $300-350$ & $1.183 \mathrm{AB}$ & $0.373 \mathrm{C}$ & $1.373 \mathrm{~B}$ \\
$\mathrm{~B}$ & $350-400$ & $1.167 \mathrm{~B}$ & $0.403 \mathrm{~A}$ & $1.357 \mathrm{C}$ \\
$\mathrm{C}$ & $400-450$ & $1.233 \mathrm{~A}$ & $0.383 \mathrm{BC}$ & $1.403 \mathrm{~A}$ \\
$\mathrm{D}$ & $450-500$ & $1.200 \mathrm{AB}$ & $0.390 \mathrm{~A}-\mathrm{C}$ & $1.383 \mathrm{~B}$ \\
$\mathrm{E}$ & $500-550$ & $1.200 \mathrm{AB}$ & $0.397 \mathrm{AB}$ & $1.383 \mathrm{~B}$ \\
\hline \multicolumn{6}{c}{} & 1.97 & 0.389 & 1.379 \\
\hline
\end{tabular}

\section{Conclusions}

An experimental study was carried out successively to determine the physical and chemical properties of mango fruits (Zebda cultivar). The obtained results can be summarized as follows:

The major, intermediate and minor diameter of mango fruit "Zebra" cultivar values ranged from 9.14 to $11.19,6.63$ to 7.54 and 5.08 to $6.40 \mathrm{~cm}$, respectively. The geometric mean diameter and arithmetic mean diameter of the mango fruits ranged from 6.62 to 7.58 and 6.94 to $8.07 \mathrm{~cm}$, respectively. The surface area, volume and real density of mango fruits values ranged from 137.61 to $188.60 \mathrm{~cm}^{2}, 368.33$ to $586.00 \mathrm{~cm}^{3}$ and 899 to $923 \mathrm{~kg} \mathrm{~m}^{-3}$, respectively. The weight of pulp, peel and seed of mango fruit values ranged from 250.00 to $414.97,44.34$ to 61.00 and 39.44 to $50.45 \mathrm{~g}$, respectively, for different sizes of mango fruits. The TSS of the mango fruits were ranged from 8.15 to $9.14 \%$. The total sugar, reducing and non-reducing sugars of the mango fruits were 7.18 to $7.73,4.55$ to 4.93 and 2.62 to $2.80 \%$, respectively, for all treatments. The chlorophyll a, chlorophyll b and carotenoids of the mango fruits were 6.29 to $6.86,3.76$ to 3.85 and 2.99 to 3.02 , respectively. The N, P and K content of the mango fruits were 1.167 to $1.200,0.373$ to 0.397 and 1.357 to $1.403 \%$ for categories A, B, C, D and E, respectively.

\section{References}

Alcantara, E.F. and Mendoza D.B. (1988). Developmental changes during growth and maturation of "Pico" fruits. Phil.; Pine Agriculturist. 1988, 7 (1) 2: 179-184.

ASAE Standard, 1984. ASAE 5352.1.moisture measurement. American Society of Agric. Eng. 2950 Niles Road, St. Joseph, MI 49085-9659.

Ashoush, A.H. and Gadallah M.O. (2011). Utilization of Mango Peels and Seed Kernels Powders as sources of Phytochemicals in Biscuit: World Journal of Dairy \& Food Science 6(1) Pp $35-42$.

Association of Official Agricultural Chemists (A.O.A.C) (2000): "Official Methods of Analysis" Benjamin Franklin Station, Washington, D.C., U.S.A., 495-510. $15^{\text {th }}$ Ed., Inc.

Bhatnagar H.C. and Subramanyam H. (2011). Some aspects of preservation, processing an export of 
mango and its products: Indian Food Packer, 27(4): Pp 33-52.

Bremmer, J. M. and Mulvaney C.S. (1982). Nitrogen-total. In: Page, A.L., Miller, R.H., Keeney, D.R. (Eds.), Methods of Soil Analysis, Part 2. Chemical and Microbiological Properties, second ed., Agronomy series No. 9 ASA, SSSA, Madison, WI, pp. 595-624.

Chandrasekar, V., Viswanathan, R. (1999). Physical and thermal properties of coffee. J. Agric. Eng. Res., 73, 227-234.

Chapman, H.D. and Partt F.P. (1961). Methods of analysis of soils, plant and water. Cal. Univ., 150200.

Chen, P. M. and Mellenthin W.M. (1981). Effect of harvest date on ripening capacity and post harvest life of Anjou pears. J. Amer. Soc. Hort. Sci., 106 (1): 38-42.

Duncan, D.B. (1955). Multiple range and multiple F. tests. Biometrics, 11: 1-42.

Fawaz Somia, A.A. (2000). Physiological studies on mango fruits handling. Ph.D. Thesis Faculty of Agriculture, Moshtohor, Zagazig University.

El-Mehrat, H.G.A. (2005). The post harvest behavior of Alphonse mango fruits responded to natural pre-harvest treatments. Ph.D. Thesis, Fac. Of Agric., Minufiya University.

Gangwar, B.M. and Tripathi, R.S. (1975). A study on physio-chemical changes during growth, maturity and ripening in mango. Punjab Hort. Jour., (1973). 13 (4): 230-236. (C.F. Hort. Abst., 45 (7): 5438).

Gofur, M.A., Shefique M.Z., Helali O.H., Ibrahim A.L., Rahman, M.M. and Hakim A. (1994). Effect of various factors on the vitamin C (ascorbic acid) content of some mango varieties grown on Rajshahi region. Bangladesh Journal of Scientific and Indsustrial Research, 29 (3): 163-171.

Gorial, B.Y. and O'Callaghan J.R., 1990. Aerodynamic Properties of Grains/Straw Materials. Journal of Agricultural Engineering Research, 46: $275-290$.

Gosh, B.N. (1969). Physical properties of the different grades of arabica beans. Transactions of the ASAE, 9(3):592-593.

Kacharu, R.P., Gupta R.K. and Alam A. (1994). Physico-Chemical Constituents and Engineering Properties of Food Crops. Scientific Publishers, Jodhpur, India, ISBN: 8172330839.

Khater, E.G. and Bahnasawy A.H. (2016). Watermelon fruits properties as affected by storage conditions. Misr J. Agri. Eng., 33 (1): $101-122$.

Khater, E.G., Bahnasawy A.H. and Ali S.A. (2014). Physical and Mechanical Properties of Fish Feed Pellets. J. Food Process. Technol. 5 (10): 378. doi: 10.4172/2157-7110.1000378

Lima, B.P., Almeida A.P., Olivier N.C. and Figueiredo N.A. (2014). Determinação das propriedades mecânicas do fruto do coqueiro anão utilizando ensaios de compressão. Evolvere Scientia, 3 (1), 219-228.

Lima, M.A.C., Silva A.L. and Azevedo S.S.N. (2009). Evolução de indicadores do ponto de colheita em manga 'Tommy Atkins' durante o crescimento e a maturação, nas condições do Vale do São Francisco, Brasil. Ciênc Agrotec, 33 (2), 432-439. http://dx.doi.org/10.1590/S141370542009000200011

Loomis, W.E. and Shull C.A. (1937). Methods in Pant Physiology. McGraw. Hill Publishing Company. Inc. New Delhi, India.

Malik, C.P. and Singh, M.B. (1980). Plant Enzymology and Histo-Enzymology. A Text Manual, pp. 276-277. Kalyani Publishing, New Delhi, India

Mann, S., Singh R. and Pandy R. (1974). Maturity studies in deshehari and Langra cultivars of mango (Mngifera indica L.). Haryana Journal of Horticultural Sciences. 3 (3/4): 97-105.

Mohsenin, N.N., 1986. Physical properties of plant and animal materials second revised. Gordon and Breach Sci. Publ., New York

Murphy, J. and Riely J.P. (1962). A modified single method for the determination of phosphorus in natural water. Anal. Chemi. Acta, 27:31-36.

Oje, K., Alonge A. F. and Adigun Y. J., 2001. Some Engineering Properties of Shear Nut Relevant to Mechanical Processing. Ife Journal of Technology, 10(2): $17-20$.

Perez-Alegria, L.R., Ciro H.J. and Abud V. L.C., 2001. Physical and Thermal Properties of Parchment Coffee Bean. Transactions of the American Society of Agricultural Engineers, 44(6):1721-1726.

Sacilik, K., Ozturk R. and Keskin R. (2003). Some physical properties of hemp seed. Biosystem Engineering, 86: 191-198.

Sivakumar, D., Jiang, Y. and Yahia, E.M. (2011). Maintaining mango (Mangifera indica L.) fruit quality during the export chain. Food Res. Int. 44, 1254-1263.

Snedecor, G.W. and Cochran W.G. (1990). Statistical Methods. $11^{\text {th }}$ ed., The Iowa state Univ. Press Ames., Iowa U.S.A., pp503-507.

Sunmonu M.O., Iyanda M.O., Odewole M.M and Moshood A.N. (2015). Determination of Some Mechanical Properties of Almond Seed Related to Design of Food Processing Machines. Department of Agricultural and Biosystems Engineering, University of Ilorin, Nigeria. Nigerian Journal of Technological Development, 12(1). Pp 22-26.

Tharanathan, R.N., Yashoda H.M. and Prabha, T.N. (2006). Mango (Mangifera indica L.), "The King of Fruits": an overview. Food Rev. Int. 22, 95-123. 
Vogal, A. (1975). A text Book of Quantitive Inorganic Analysis. Longmaus, New York, pp. 1216.

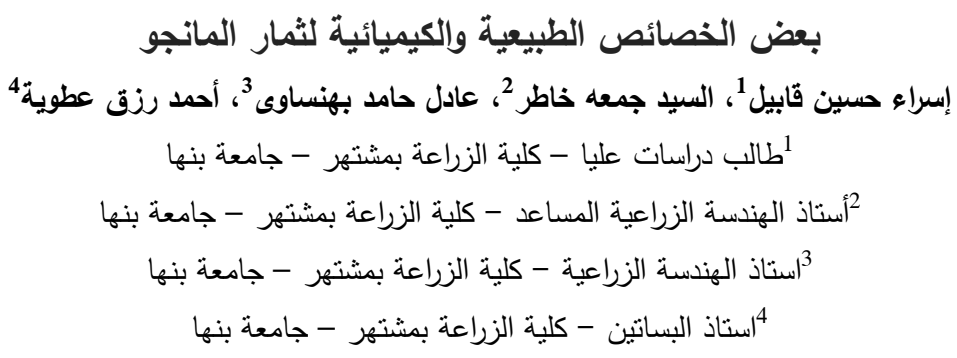

يهدف هذا البحث الى دراسة الخصائص الطبيعية والكيميائية لثمار المانجو. وكانت اهم النتائج المتحصل عليها: تراوح كلا من القطر الرئيسى والمتوسط والاصغر لثمار المانجو صنف زيبدة ما بين 9.14 - 11.19 و6.63 - 7.54 و 5.08 - 6.40 سم، على التوالى. تراوح كلا من متوسط القطر الهندسى ومتوسط القطر الحسابى ما بين 6.62 الى 7.58 و6.14 الى 8.07 سم على التوالى. ثراوح كلا من المساحة السطحية والحجم والكثافة الحقيقية لثمار مانجو ما بين 137.61 الى 188.60 سم²ومن 1368.33 اللى 586.00 سم ومن 899 الى 923 كجم م -3 على التوالى. تراوح منوسط وزن العصير والقنر والبذرة لثمار المانجو ما بين 250.00 الى ومن 44.34 الى 61.00 ومن 39.44 الى 50.45 جرام على

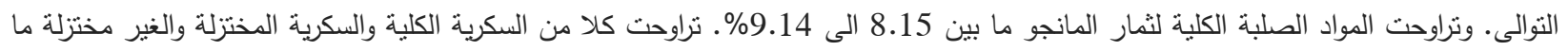
بين 7.18 الى 7.73 ومن 4.55 الى 4.93 ومن 2.62 الى 2.80\% على الترتيب. تراوح كلا من كلوروفيل أ و ب والكربوهيدرات لثمار المانجو ما بين 6.29 الى 6.86 ومن 3.76 الى 3.85 ومن 2.99 الى 3.02 \% على الترتيب. تراوح كلا من محتوى ثمار المانجو من النيتروجين والبوتاسيوم والفوسفور ما بين 1.167 الى 1.200 ومن 0.373 الى 0.397 ومن 1.357 الى 1.403 \% على الترنيب.

الكلمات المفتاحية: المانجو - الخصائص الطبيعية - الخصائص الكيميائية - الابعاد - المساحة السطحية - الحجم - الكثافة - المواد الصلبة الكلية الذائبة 